\title{
The Role Of The Sharia Supervisory Board (DPS) In Supervision Of Contract Implementation At The Binjai Branch Bri Sharia
}

\author{
Abi Waqqosh ${ }^{1}$, Fani hairani yusfa ${ }^{2}$, Sri Sudiarti ${ }^{3}$, Tri Dessy Fadillah ${ }^{4}$, Haris Al Amin ${ }^{5}$ \\ ${ }^{1,2,4}$ STAI Syekh H Abdul Halim Hasan Al Ishlahiyah Binjai \\ ${ }^{3}$ Universitas Islam Negeri Sumatera Utara, ${ }^{5}$ Politknik Negeri Lhokseumawe \\ Email Corespondent : abipaytren@gmail.com
}

\begin{abstract}
This study aims to determine the position and function of DPS in contract making, supervision of contract implementation, and the effectiveness of contract supervision at Bank BRI Syariah Binjai Branch. In this research, the researcher conducted research using qualitative methods. Research that uses a qualitative approach aims to explore or build a proportion or explain the meaning behind reality. Researchers are based on reality or events that take place in the field. Qualitative research methods can be interpreted as research that produces descriptive data, regarding spoken and written words, and observable behavior of the people being studied. Qualitative research is also research that produces descriptions in the form of words or verbally from the phenomenon under study or from people who are competent in their fields. The results of this study are that the position and function of the DPS in drafting the BRI Syariah Bank contract is appropriate. In general, what is being done is to supervise all forms of activities related to existing contracts in the bank. This supervision also takes the form of standardizing and ratifying contract standards that apply nationally in the sense that it applies to all BRI Syariah branches, as well as assisting parties in disseminating information to BRI Syariah branches in the regions.
\end{abstract}

Keywords: Sharia Bank, Sharia Supervisory Board, Contract Execution

\begin{abstract}
Abstrak : Penelitian mi bertujuan untuk mengetahui kedudukan dan fungsi DPS dalam pembuatan kontrak, pengawasan pelaksanaan kontrak, dan efektivitas pengawasan kontrak pada Bank BRI Syariah Cabang Binjai. Dalam penelitian mi peneliti melakukan penelitian dengan metode kualitatif. Penelitian yang menggunakan pendekatan kualitatif bertujuan menggali atau membangun satu proporsi atau menjelaskan siakna dibalik realita. Peneliti berpijak dari realita atau peristiwa yang berlangsung di lapangan. Penelitian metode kualitatif dapat diartikan sebagai penelitian yang menghasilkan data-data deskriptif, mengenai kata-kata lisan maupun tulisan, dan tingkah laku yang dapat diamati dari orangorang yang diteliti. Penelitian kualitatif juga merupakan penelitian yang menghasilkan deskripsi berupa kata-kata atau lisan dari fenomena yang diteliti atau dari orang-orang yang berkompeten di bidangnya. Adapun hasil penelitian ini yaitu bahwa kedudukan dan fungsi DPS dalam pembuatan draft kontrak Bank BRI Syariah telah sesuai. Secara umum hal yang dilakukan adalah mengawasi segala bentuk kegiatan yang berhubungan dengan akad-akad yang ada di bank. Pengawasan tersebut juga berwujud seperti membakukan dan mengesahkan standar akad yang berlaku nasional dalam arti berlaku di semua cabang BRI Syariah, juga membantu pihak dalam mensosialisasikan ke cabang-cabang BRI Syariah di daerah-daerah.
\end{abstract}

Kata Kunci: Bank Syariah, Dewan Pengawasan Syariah, Pelaksanaan Kontrak 


\section{INTRODUCTION}

In an effort to purify the services of Islamic financial institutions so that they are truly in line with the provisions of Islamic sharia, the existence of a Sharia Supervisory Board (DPS) is absolutely necessary. DPS is a key institution that ensures that the operational activities of Islamic financial institutions are in accordance with sharia principles. In order to streamline the implementation of the duties of sharia supervisors, it is necessary to increase DPS knowledge about banking operations, economic knowledge both fiscal, monetary, accounting and so on as well as the intensity of its involvement in determining new products and socialization programs. The alternative economy is manifested in an economic system that uses religious regulations as its legal basis (Mukhtar, 2005). This needs to be done so that Islamic banks avoid usury and run in accordance with Islamic sharia.

Supervision is one of the basic tasks of management in the modern management concept, which is to ensure that everything is in order, running according to prescribed lines, existing theories, and reliable foundations. The supervisory system in the institution has existed for a long time, namely the supervisory system applied during the time of Umar Ibn Khattab, this supervision includes the following:

1. Ensuring the implementation of the rules of economic activity which include the stipulation of economic activities, perfecting work, fighting fraud, not endangering others.

2. Create security and tranquility.

3. Supervise the condition of the people.

4. Forbid others to make water flow without need.

5. Safeguard the public interest.

6. Regulate transactions in the market (Al-Harist, 2006).

The Sharia Supervisory Board has an important role in the development of Islamic banking in Indonesia. There are three important reasons DPS has an important role in Islamic banks, including:

1. Determine the level of credibility of Islamic Banks.

2. The main element in creating sharia compliance guarantees

3. One of the main pillars in the implementation of Good Corporate Governance (GCG) of Islamic banks.

So that the role and function of the Sharia Supervisory Board in Islamic banks must be maintained, strengthened its position, and optimized its function and role in sharia supervision to create Indonesian sharia banking that is healthy, efficient, and in accordance with sharia principles and rules.

The development of Islamic banking in Indonesia from year to year continues to increase. With the issuance of Law no. 10 of 1998 concerning amendments to law no. 7 of 1992 concerning banking, which was followed by the issuance of a number of implementing provisions in the form of a BI board of directors decree/Bank Indonesia regulations, has provided a stronger legal basis for the development of Islamic banking in Indonesia. (Nurul Huda and Mustafa Edwin, 2009).

The current phenomenon in the practice of sharia supervision in Islamic banks in Indonesia is that the DPS's vital role has not run optimally, even though it is very far from the role they should carry out. Many of them have no role at all in supervising Islamic banking operations. As it is known that DPS must supervise and check the format and contract in the bank, how Islamic banks carry out restructuring, rescheduling, how to set margins, and so on.

\section{LITERATURE REVIEW}

\section{Definition of Sharia Supervisory Board (DPS)}

In the Indonesian dictionary the word "board" is a body consisting of several people whose job is to decide something by negotiating, the supervisor comes from the word awas which means supervisor. (Depdiknas, 2005). Meanwhile, sharia is all points of God that relate to human behavior outside of morals. Sharia can also be interpreted as a name for laws that are amaliah (Amir, 2005).

The sharia supervisory board is an independent institution or judge specialized in fiqh muamalat (Figh Al-Muamalat). However, DPS can also be members outside of fiqh experts but also experts in the field of Islamic financial institutions and muamalat fiqh. The sharia supervisory board is an institution that is obliged to direct, review, and supervise the activities of financial institutions so that they can be assured that they comply with the rules and principles of Islamic sharia (Sofyan, 2002).

\section{History of the Establishment of DPS}

Around the 1990s the attention of Muslims in Indonesia to economic teachings based on sharia began to grow and develop. Seeing this reality, MUI together with other institutions, especially Bank Indonesia, gave a positive and proactive response. One of the results was the birth of Bank Muamalat Indonesia in 1992 as the first bank in Indonesia based on sharia principles in its transaction activities. 
The birth of Sharia Banks was then followed by other banks, both in the form of full branches and those only in the form of divisions or sharia business units. Not to forget, other financial institutions such as insurance and sharia-based investment institutions continue to emerge.

In order to further increase the khidmah and fulfill the expectations of the people, the MUI in February 1999 formed the DSN. This institution, which consists of experts in Islamic law (fuqaha) as well as economic experts and practitioners, especially the financial sector, both bank and non-bank, functions to carry out the MUI's tasks in encouraging and advancing the people's economy. In addition, they are tasked with, among other things, exploring, reviewing, formulating the values and principles of Islamic law (Sharia) to be used as guidelines in transaction activities at Islamic Financial Institutions (DSN-MUI and BI, 2001). In the event that the appointment of prospective members of the sharia supervisory board by the general meeting of shareholders is carried out prior to BI approval, the appointment will only be effective if the DPS member has been approved by Bank Indonesia (Adiwarman, 2013).

\section{RESEARCH METHODS}

In this study the authors conducted research with qualitative methods. Research that uses a qualitative approach aims to explore or build a proportion or explain the meaning behind reality. Researchers are based on reality or events that take place in the field (Burhan, 2004). Qualitative research methods can be interpreted as research that produces descriptive data, regarding spoken and written words, and observable behavior from the people being studied (Bagong, 2005). Qualitative research is also research that produces descriptions in the form of words or verbally from the phenomena being studied or from people who are competent in their fields (Lexy, 2010).

\section{Data source}

The source of the data in the study is the subject from which it can be obtained. According to Lofland and Lefland, as quoted by Moleong that "the main source in qualitative research is words or actions, the rest is additional data such as documents and others" (Lexy, 2010). Research data can come from various sources, depending on the type of research and what data will be needed. Based on the source of the data, Suharsimi Arikunto said that "the subject of this research is where the data was obtained" (Lexy, 2010).
The informants in this study were at BRI Syariah Bank Binjai Branch. The data sources that can be used in this study are based on source data, namely:

a. Primary data is an information and data obtained by the author directly from the place of research or the object of research. The data obtained is the result of interviews with the leadership of Bank BRI Syariah Binjai Branch.

b. Secondary data in the form of data that is already available and can be obtained by the author by reading, viewing or listening to it. In this study, the authors will obtain data in the form of financial reports and information from the internet and journals.

\section{Data Collection and Recording Procedure}

In this study there are several data collection techniques used. Data collection activities are a strategic step in research because the main purpose of research is to obtain data. The data collection techniques used in this study include:

1. Interview

"The interview is a process of verbal interaction and communication with the aim of obtaining important information. An interview is a conversation carried out by two parties for a specific purpose or purpose. Interviews are conducted by the interviewer (interviewer) by asking questions to the interviewee (interviewer) or the person who provides answers to the questions asked" (Lexy, 2010). This study uses a semistructured interview technique. Semistructured interviews are more flexible than structured interviews because they are not tied to interview guidelines. The interview guide used is only in the form of topics or an outline of the theme of the problem that will be asked in the interview. Questions can be developed according to the social situation in the field.

Data collection through interviews in this study was conducted with bank leaders and several employees at Bank BRI Syariah Binjai Branch to determine the analysis of HR development in customer service quality, as well as supporting and inhibiting factors in its 
implementation at that location. In order for the interview results to be recorded properly, in this study the researcher used a notebook to record important things at the time of the interview, a recorder to record the ongoing interview process to make it easier for researchers when completing interview data, and a camera to photograph activities. interview.

\section{Observation}

Observation is an activity of direct observation to observe a social situation. Observations were made using human senses. The senses involved in observation activities include the sense of sight, the sense of hearing, the sense of smell, the sense of taste and so on. Observation is directed at paying attention to activities accurately, noting phenomena that arise, and considering the relationship between aspects of the phenomenon. Observation aims to describe the setting being studied, the activities that take place, the people involved in the activity, and the meaning of the observed events. According to Sugiyono "Observation can find things that are not obtained through interviews with respondents because they are sensitive or want to be covered" (Sugiyono, 2013).

\section{Documentation}

Documentation study according to Haris Herdiansyah: "is a method of collecting qualitative data which is done by viewing and analyzing written media or documents to get an overview from the subject's point of view" Sugiyono also explained that "Documents are records of events that have passed in the form of writing, pictures, and works" (Haris, 2010) The purpose of using documents in research is to support research results to make them more credible or trustworthy.

\section{RESULTS AND DISCUSSION}

In relation to the supervision of contract implementation at BRI Syariah, according to $\mathrm{Mr}$. Lukita Tri Prakasa, DPS did what DPS did at BRI Syariah bank:

"First, DPS will look at the flow and the scheme, what kind of business process, what customer comes to the bank, what need is there, what customer fills in the form, the form will be checked, the bank must convey how the process is, and how much profit. I know that after receiving an explanation. DPS checks the contract, we submit the contract, sir, the contract that we will use. So it's more or less a discovery like that. BRI Syariah Bank DPS is young so it's active."

The main thing that must be considered by DPS is looking at the implementation of the contract in terms of fulfilling the pillars and conditions of the contracts. For example in a murabahah contract, if at first the object of murabahah financing (murabaha contact) is unknown, and or not written, then the pillars and conditions of the contract (murabbaha) are not fulfilled, and that means the contract is invalid. It is their duty to prevent these violations from happening again.

In the future the possibility of irregularities in Islamic banks is not impossible, even though there is a Sharia Supervisory Board (DPS) because even a DPS is an ordinary human being who is not free from mistakes. Especially now that there are more and more Islamic banking, and the number of Islamic bankers is increasing.

To deal with deviations that may occur, this is where the role of DPS in Islamic banks must be maximized. In terms of maximizing DPS performance According to Mr. Muhamad Nadratuzzaman Hosen, one of the central MUI administrators:

"The function of DPS in Islamic banks is to maintain shariah compliance in bank activities. Actually, DPS is obliged to supervise all bank activities, be it funding products, lending, marketing and other things related to bank activities. For that, a check list is needed. all activities of Islamic banks, and in fact until now this has not existed in Islamic banks."

In carrying out bank activities, there are no mistakes made by the bank. So that there is a lot of slanted news about violations of sharia principles in Islamic bank institutions, according to Pak Lukita regarding the issue of contract implementation at BRI Syariah Bank which is not in accordance with the rules, it's just a process error, as he said as follows: 
"Yes, at least there is an incorrect process that occurs in the field, such as taking over by directly using a murabahah contract. But it comes from conventional because $70 \%$ of the truth comes from conventional outside sharia but there are no big problems. mailing lists that preach about non-sharia bank products, now where is the reference if we are the DSN and they make their own reference based on the paradigm they are bothered by dealing with things like this because we are not one voice here, there are many schools of thought here, we follow what has been conveyed by the MUI. Don't make any more fatwas based on your own paradigm. That's why I look at the mailing list. In my opinion, things like this don't support the development of Islamic economics."

In general, the violations that occur can be classified into two, namely major violations and minor violations.

First, violations of a major nature or of a large nature that can be fatal, according to Gunawan Yasni, a member of the DPS at BRI Syariah, the violation was never found by the DPS.

Both violations are minor in nature, or violations of a small scale. This minor-scale violation has been encountered by DPS, for example in murabahah financing on motorcycles.

The explanation of the minor violations in murabaha is more or less like the example that the bank does not have a direct relationship with the dealer of a certain motorcycle product, which is directly related to the dealer. If there is a purchase of a motorcycle or car, it is a customer of the bank. So that those who deal directly with motorcycle or car dealers are bank customers and those who take the goods are customers. In fact, the ideal is that if you do a murabahah contract, the bank is buying and selling motorcycles, so that the bank is directly related to the dealer. The customer needs a motorbike, or the customer needs a car, the bank sells the motorbike or car from the dealer to the customer so that the customer only knows he is buying and selling with the bank, he pays the installments for the motorbike he bought or the car he bought to the bank but because of the context of this financing, this does not happen. customers dealing with dealers. Now in this case there must be a wakalah contract (representative contract) that the bank represents to the customer. Verbally, the bank can say to the customer, "Please buy a car or motorbike that you are proposing on behalf of the bank, then the bank will sell it to you". The wakalah contract must be fulfilled in the contract in the murabahah contract because it is a condition of murabahah financing which is carried out if the bank is not in direct contact with the dealer. The problem in this case is that what DPS usually finds is in the branches of the wakalah contract. no, even though the customer is clearly in direct contact with the dealer.

Related to overcoming this, the solution that can be taken by DPS is to anticipate or take proactive actions from violations committed by BRI Syariah Bank. According to Mr. Gunawan Yasni, "We can provide solutions for minor violations committed by banks in the form of pro-active actions that can be carried out by banks by way of: the wakalah contract does not have to be notarized, the wakalah contract is only from both parties, the terms are underhanded. friends who are in the account officer who is doing the financing to complete it immediately. So still formally it must be there, the correspondence must be there. He must sign on a stamp duty that the bank represents to the customer what to buy at what cash price, which then this is a murabahah agreement, the truth is that it states that the object of murabahah is the item purchased through the customer's representative, what is the value, what is the item. So just completing it is a violation if in our calculations it is a minor violation, but because of that the conditions must be fulfilled so it is completed later.

The treatment of sharia banking must be the same as other banks in terms of compliance with applicable laws and regulations. As a trust institution, Islamic bank administrators must be able to carry out public trust, especially with the mission of Islamic da'wah. Therefore, based on sharia principles which state that a person who is proven to have committed a violation that causes harm to another party, is obliged to take responsibility for his actions and be given sanctions according to the violation he committed The management of Islamic banks is no exception to the sharia supervisory board that is proven to have committed negligence and violations must be given 
sanctions for violations committed according to laws and regulations.

In the implementation of existing contracts in Islamic banks according to Mr. Muhamad Nadratuzzaman Hosen:

"Let the DPS in charge of supervising bank activities have a deep understanding of banking science and understand well about Islamic sharia. If from a bank contract, for example home financing, this financing certainly requires a notary. So in this case the notary must also understand Islamic sharia but in reality this is has not been realized so that there are still many Islamic Banks whose mudharabah and murabahah contracts are of the same form."

In this regard, the DSN and DPS as a forum for each bank and the only parties who have the right to issue fatwas on products and services of Islamic Financial Institutions (LKS) and oversee their implementation have the authority to declare that there has been a violation of sharia principles. check regularly on these incidents so that the positive legal aspects and sharia law can be fulfilled.

In a Bank Indonesia Circular Letter (SE BI) it is stated that one of the obligations of DPS is to review all bank activities, both central Islamic banks and branch Islamic banks spread throughout Indonesia. Meanwhile, the supervisory system of the sharia supervisory board for BRI Syariah Bank, both at the center and its branches, as stated by $\mathrm{Mr}$. Lukita:

"We have a minimum of once every 2 weeks, where the DPS meets or there are no cases. Yesterday, they produced more than 40 opinions, so that's not just an opinion, but we also only consult, often consultations rather than opinions happen, Mr. Gunawan is the most active in the community. BRI Syariah. At least every week or 2 weeks he is here, sometimes we consult outside the DPS meeting but the activities of the audit are through cross checks from the arm of our internal audit. So DPS does not go around the branch, but there are some he asks to visit the branch "I want to visit this branch" so it is active even though sometimes not directly but through the hands of an arm of the DPS. So our own DPS has a sharia compliance unit, it is in the compliance unit, there it provides evidence of compliance in general, so he saw how the process was going, many DPS accomplices actually here there is an internal audit process, there is sharia compliance unit, which is in the group's management and compliance is stronger if DPS is at BRI Syariah."

The presence of Islamic Banks in Indonesia is nothing but an effort by Muslims to base all aspects of their economic life based on the Qur'an and AsSunnah by maintaining the trust of the people who entrust their funds to Islamic banks, aiming to avoid usury which is forbidden by Allah SWT. However, there are still banks that are involved in financing that contains interest. This is where the function of the DPS is to oversee the compliance of syfaiah banks to Islamic principles. According to $\mathrm{Mr}$. Gunawan Yasni, the actions of DPS if it finds that the implementation of the contract at BRI Syariah Bank deviates from the sharia provisions are:

1. Tabayyun, examined more deeply the existing problems, whether there were really mistakes made by Islamic banks.

2. If it is proven true to commit a violation, and the bank has received a margin (profit). Then DPS will decide that the margin is not halal but non-halal and should not be recognized as income but must be allocated to BAZNAS or to other social institutions as ta'zir for violations committed by banks.

The working mechanism of the DPS at BRI Syariah, basically the main task of the DPS is to provide an opinion on the product as a whole and provide an opinion on the implementation of Islamic commercial banks as a whole in BRI Syariah Bank. There is also a mechanism for filing a sharia opinion against DPS related to products at BRI Syariah Bank, namely:

1. The Bank submits an opinion to the DPS a week before the regular DPS meeting, it is intended that before being discussed in the meeting, the members of the DPS can read and understand the products that will be issued by the Islamic bank;

2. The opinion is discussed at the regular DPS meeting;

3. The bank concerned will make a draft opinion submission;

4. At the next DPS routine meeting, the sharia opinion is ratified if it has become an agreement and there are no more mistakes in words; 
The Role Of The Sharia Supervisory Board (Dps) In Supervision Of Contract Implementation At The Binjai Branch Bri Sharia

Abi Waqqosh ${ }^{1}$, Fani hairani yusfa ${ }^{2}$, Sri Sudiarti ${ }^{3}$, Tri Dessy Fadillah ${ }^{4}$, Haris Al Amin ${ }^{5}$

5. Opinions that have been ratified are recorded, and become a standard sharia opinion on the product;

6. Sharia opinion contains the product to be issued by the bank and contains information on how to advertise the product.

To achieve the objectives of developing sharia banking, in addition to the need to improve the operational provisions, both institutional, business activities, monetary instruments, the development of Human Resources (SDI) is also needed. In connection with this SDI, in the early days of the establishment of Bank Uraum BRI Syariah, it was an obstacle for DPS in supervising contracts in Bank BRI Syariah because Human Resources (SDI) were still insufficient but over time, now the problem is no longer sufficient. there is more because Bank BRI Syariah continues to carry out up grading.

\section{CONCLUSION}

1. The results showed that simultaneously the independent variables inflation, GDP, gold price, CAR, and NPF have a significant effect on ROA at PT Bank Syariah Mandiri in Indonesia

2. The results showed that partially the independent variables GDP and NPF had a significant effect on ROA at PT Bank Syariah Mandiri in Indonesia, while the variables of Inflation, Gold Price, and CAR had no significant effect on ROA at PT. BSM in Indonesia.

3. The results showed that the relationship between the independent variable and the dependent variable had a very high closeness, namely $82.2 \%$ and the ability of the independent variable to explainthevariable dependentreached $67.6 \%$. While the remaining $32.4 \%$ is influenced or explained by other variables not included in this study.

\section{REFFERENCE}

Al-Shodiq, Mukhtar, 2005. Briefcasebooks Edukasi Professional Syariah: Fatwa-Fatwa Syariah Kontemporer, Jakarta, Renaisan.

Amir Syarifuddin, 2005. Ushul Fiqh, Jakarta, PT. Logos Wacana Ilmu.

Bungin, Burhan Bungin. 2004. Metode Penelitian Kualitatif, Jakarta: PT. Raja Grafindo Persada.

Depdiknas, 2005. Kamus Besar Bahasa Indonesia, ed III, Jakarta, Balai Pusaka.

DSN-MUI dan BI, 2001. Himpunan Fatwa Dewan Syariah Nasional untuk Lembaga Keuangan Syariah, Jakarta: DSN-MUI dan BI . Cet Pertama.

Harahap, Sofyan Syafri. 2002. Auditing dalam Perspektif Islam, Jakarta, Pustaka Quantum

Herdiansyah, Haris. 2010. Metodologi Penelitian Kualitatif untuk Ilmu-ilmu Sosial, Jakarta: Salemba Humanika.

Huda, Nurul Mustafa Edwin Nasution, 2009. Curent Issues Lembaga Keuangan Syariah, Jakarta, PT. Kencana.

Jaribah, Al-Harist bin Ahmad, 2006. Fikih Ekonomi Umar bin Al-Khathab, (Jakarta, KHALIFAH Pustaka Al-Kaustar Group).

Karim, Adiwarman. 2013. Bank Indonesia : Analisis Fiqih dan Keuangan Jakarta: Rajawali Press. 
The Role Of The Sharia Supervisory Board (Dps) In Supervision Of Contract Implementation At The Binjai Branch Bri Sharia

Abi Waqqosh ${ }^{1}$, Fani hairani yusfa ${ }^{2}$, Sri Sudiarti ${ }^{3}$, Tri Dessy Fadillah ${ }^{4}$, Haris Al Amin ${ }^{5}$

Moeloeng,Lexy J. 2010. Metode Penelitian Kualitatif, Bandung: PT. Remaja Rosda Karya.

Sugiyono. 2013. Metode Penelitian Pendidikan, Bandung: Alfabeta.

Suyatno, Bagong. 2005. Metode Penelitian Sosial, Jakarta: Kencana Prenada Media Group. 